\title{
The endophytic fungi from South Sumatra (Indonesia) and their pathogenecity against the new invasive fall armyworm, Spodoptera frugiperda
}

\author{
MIMMA GUSTIANINGTYAS ${ }^{1}$, SITI HERLINDA ${ }^{1,2,3, \boldsymbol{v}}$, SUWANDI SUWANDI $^{1,2,3}$ \\ ${ }^{1}$ Program of Crop Sciences, Faculty of Agriculture, Universitas Sriwijaya. Jl. Raya Palembang-Prabumulih Km. 32, Indralaya, Ogan Ilir 30662, South \\ Sumatra, Indonesian \\ ${ }^{2}$ Department of Plant Pests and Diseases, Faculty of Agriculture, Universitas Sriwijaya. Jl. Raya Palembang-Prabumulih Km. 32, Indralaya, Ogan Ilir \\ 30662, South Sumatra, Indonesian. Tel.: +62-711-580663, Fax.: +62-711-580276, ‘email: sitiherlinda @unsri.ac.id \\ ${ }^{3}$ Research Center for Sub-optimal Lands, Universitas Sriwijaya. Jl. Padang Selasa No. 524, Bukit Besar, Palembang 30139, South Sumatra, Indonesia
}

Manuscript received: 17 January 2021. Revision accepted: 26 January 2021.

\begin{abstract}
Gustianingtyas M, Herlinda S, Suwandi. 2021. The endophytic fungi from South Sumatra (Indonesia) and their pathogenicity against the new invasive fall armyworm, Spodoptera frugiperda. Biodiversitas 22: 1051-1062. Maize in Indonesia is currently experiencing attacks and outbreaks of the new invasive fall armyworm, Spodoptera frugiperda. The S. frugiperda larvae emerge from the leaf midrib when eating, after hiding in the maize stalk so that it is difficult to control by contact. This study aimed to find out the endophytic fungi from the roots of maize, banana and chili in South Sumatra and to determine their pathogenicity against S. frugiperda larvae. The endophytic fungi were isolated from the plant roots. Fungal isolates proven to be endophytic were dropped $\left(1 \times 10^{6}\right.$ conidia $\mathrm{mL}^{-1}$ ) on the second instar larvae. The result showed that the endophytic fungi found were 8 isolates consisting of the genus, Aspergillus sp., Beauveria sp., Chaetomium sp., and Curvularia sp. First report of Aspergillus sp., Chaetomium sp., and Curvularia sp. have insecticidal activity against $S$. frugiperda larvae. However, the two most pathogenic isolates were $\mathrm{JgCrJr}$ and $\mathrm{JgSPK}$ isolates of Beauveria sp. with larval mortality of $29.33 \%$ and $26.67 \%$, respectively, and could reduce the emergence of $S$. frugiperda adults up to $44 \%$. So, the two isolates of Beauveria sp. have a high potential to be developed to control S. frugiperda larvae in maize both in the lowlands and the highlands.
\end{abstract}

Keywords: Aspergillus, Beauveria, Chaetomium, Curvularia, insecticidal activity

\section{INTRODUCTION}

Maize in Indonesia is currently facing a big problem in invasion and outbreaks of newcomer insect pests, namely the fall armyworm (Spodoptera frugiperda) (Lepidoptera: Noctuidae). S. frugiperda comes from South America (Nagoshi et al. 2017; Otim et al. 2018) and entered Indonesia for the first time on March 26, 2019 in West Sumatra, then in June 2019 it was found in Banten and West Java (Sartiami et al. 2020) and now it has spread rapidly to various provinces in Indonesia, such as South Sumatra (Herlinda et al. 2020b; Hutasoit et al. 2020), Lampung (Lestari et al. 2020), and Bengkulu (Ginting et al 2020). The fall armyworm has caused maize yield losses in Africa of 250-630 million US dollars per year (Bateman et al. 2018). Kenya lost maize production of up to 1 million tons per year (De Groote et al. 2020). In Indonesia, the pest was reported to attack both hybrid maize and local maize varieties (Ginting et al.2020). The pest is polyphagous because they are able to attack and damage various species of plants from various families, for example, maize, rice, sugar cane, cotton, and ornamental plants (Montezano et al. 2018). The $S$. frugiperda larvae can eat greedily on leaves, stems, flowers, fruit, growing points, fruit, and the whole maize until it is bare (Ginting et al. 2020).
To overcome the invasion and outbreaks of $S$. frugiperda, synthetic insecticides are generally used in the world (Tambo et al. 2020). The synthetic insecticides of organophosphates and carbamates (Boaventura et al. 2020) and other synthetic insecticides have been shown to be resistant to the fall armyworm (Gutiérrez-moreno et al. 2018) and even the entomopathogenic bacterium, Bacillus thuringiensis $(\mathrm{Bt}$ ) can be broken by $S$. frugiperda (Flagel et al. 2018). Another control method that has not shown resistance is the use of the entomopathogenic fungi (fungi causing disease in insects). The entomopathogenic fungi that have been shown to be effective at killing the insect pests of the genus Spodoptera are Beauveria bassiana, Metarhizium anisopliae (Ayudya et al. 2019; Gustianingtyas et al. 2020), Penicillium citrinum, and Talaromyces diversus (Herlinda et al. 2020a). S. frugiperda was also killed by B. bassiana, M. anisopliae, Metarhizium rileyi (Ramanujam et al. 2020), and Metarhizium spp. (Herlinda et al. 2020b). The entomopathogenic fungus species effectively killed $S$. frugiperda larvae by contact (Herlinda et al. 2020b). If the mode of action of the fungus is contacted only, the fungus is not very effective in controlling S. frugiperda larvae hidden in maize leaf midribs because the larvae only appear when eating leaves in the morning (Bentivenha et al. 2017). In the field, the $S$. frugiperda larvae were found appearing on leaf surfaces 
from 6.30 a.m. to 8.00 a.m. To control the larvae of $S$. frugiperda, it is more effective to use an endophytic entomopathogenic fungus because the endophytic fungi are those that systemically colonize host plant tissues, associating mutually, and without being pathogenic to the host plants (Lira et al. 2020; Kasambala et al. 2018). The endophytic fungus has many advantages, apart from having a mode of action through stomach poison (Russo et al. 2020), it can also kill by contact (Ramirez-Rodriguez and Sánchez-Peña 2016), and it can also stimulate plant growth (Jaber and Ownley 2018; Ahmad et al. 2020; Bamisile et al. 2020; Barra-Bucarei et al. 2020). The endophytic fungi pathogenic to $S$. frugiperda larvae need to be found from maize and other plant tissues in Indonesia, especially in South Sumatra and are expected to be potential alternatives to the use of synthetic insecticides. The objectives of this research were to find out the endophytic fungi from maize, banana and chili roots around the maize ecosystem in South Sumatra and to determine their pathogenicity against S. frugiperda larvae.

\section{MATERIALS AND METHODS}

This study has been conducted at the Entomology Laboratory, Department of Pests and Plant Diseases, Faculty of Agriculture, Sriwijaya University from February to December 2020. The maize cultivation for S. frugiperda mass rearing has been conducted from February to December 2020 and the mass rearing from April to November 2020. The fungi exploration and identification have been performed since April 2020. The fungi were identified at the Laboratory of Agricultural Biotechnology (accredited according to the ISO/IEC 17025 standard), Department of Plant Protection, Faculty of Agriculture, Universitas Lampung, Indonesia. The bioassay was conducted from October to December 2020. It was carried out in an incubator at a constant temperature and relative humidity (RH), namely $30{ }^{\circ} \mathrm{C}$ and $93 \%$, respectively. All endophytic fungal isolates used in this experiment were explored from the lowlands to highlands of South Sumatra, Indonesia.

\section{Exploration, isolation, and purification of endophytic fungus}

The exploration of endophytic fungi was carried out by taking the roots of maize, bananas and vegetables (chili) around the maize ecosystem. The survey locations for sampling the fungi were carried out in maize production centers in South Sumatra from lowlands to highlands (Table 1). The individual plants selected following the method of Kasambala et al. (2018) had the most healthy characteristics, and were not attacked by pests or diseases. Parts of plant tissues taken were the roots of maize, bananas and vegetables (chili) around the maize ecosystem. Furthermore, the root samples were wrapped in sterile straw paper and given the code name of the plant, location, date of sampling, and soil $\mathrm{pH}$ then put into a plastic zipper and placed in an icebox, then taken to the laboratory.
In the laboratory, the plant root samples were washed using aseptically under running tap water. The surface sterilization and sample isolation were carried out to avoid unwanted airborne microspore contamination. In the laminar airflow cabinet, the plant roots were cut to a size of $0.5 \mathrm{~cm} \times 0.5 \mathrm{~cm}$, then the surface was sterilized, modifying the method of Elfita et al. (2019) by immersing plant tissue in $70 \% \mathrm{EtOH}$ (Ethyl alcohol) for 2 minutes, then dipping it in $1 \% \mathrm{NaOCl}$ (Sodium hypochlorite) for 1 minute, then rinsed three times in the sterile distilled water for 1 minute. To determine the success of this surface sterilization, the last rinse was grown onto Potato Dextrose Agar (PDA) which modified the method of Russo et al. (2020). If the PDA media did not grow the microorganisms, it meant that the surface sterilization was successful (RamirezRodriguez and Sánchez-Peña 2016).

The surface of the sterile roots was isolated following the method of Elfita et al. (2019) in the laminar airflow cabinet by growing onto the malt extract agar (MEA) media. The MEA media was the specifically selected media for growing fungi isolated from the root tissue (Silva et al. 2018). The roots grown on the MEA media were as many as five pieces $(5 \mathrm{~mm}$ in length and $1-5 \mathrm{~mm}$ in diameter) and incubated for 7 days at room temperature. The fungus growing from the root was then purified to get an isolate. After the isolates were isolated, the fungal isolates aged 7 days were observed for their colony color and shape, hyphae and conidial shape, and continued with an assessment of their colonization ability to enter plant tissue.

\section{Inoculation of endophytic fungi into plant tissue}

The isolated fungi were then inoculated into the maize tissue to ensure that the fungus was endophytic. The maize seeds already sterilized using the Elfita et al. (2019) method were then soaked as many as 15 seeds in $10 \mathrm{~mL}$ of the fungi suspension with a concentration of $1 \times 10^{6}$ conidia $\mathrm{mL}^{-1}$ for 6 hours. The control seeds were not soaked with the fungal suspension but soaked in $10 \mathrm{~mL}$ of distilled water. All treatments (isolates and controls) in this experiment were repeated three times. Then, the seeds were grown in a sterile glass bottle (volume $250 \mathrm{~mL}$ ), which is based on a sterile filter paper (Whatman no. 42) moistened with $1 \mathrm{~mL}$ distilled water, and incubated for 10 days in the sterile laminar flow cabinet. In the 10-day-old plants, the stem tissue was sliced crosswise and longitudinally with a thickness of $0.02 \mathrm{~mm}$ each and stained with $0.05 \%$ lactophenol trypan blue dye to be observed with a light microscope at $40 \mathrm{x}$ magnification to detect the presence of penetrating endophytic fungal mycelium in the plant tissue. The plant tissue colonized by the endophytic fungi was evidenced by the presence of the fungal tissue in the form of mycelia which grew to fill the plant tissues. The fungi proven to be endophytic were then observed for color and colony shape, hyphae and conidial shape, and the conidial size measure to obtain distinctive features used for species identification. The fungi were identified based on their morphological characteristics using the taxonomic books of Humber (2005) and El-Ghany (2015). 


\section{Calculation of conidial density and viability}

Only the endophytic fungal isolates were used for bioassays against $S$. frugiperda larvae. Before the bioassay was carried out, first the density and viability of each isolate were calculated. The conidial density calculations were carried out on the endophytic fungi aged 7 days. The conidial density was enumerated following the method of Sumikarsih et al. (2019) using a hemocytometer and observed with a light microscope at $40 \mathrm{x}$ magnification. The viability was observed by growing $1 \mathrm{~mL}$ fungal suspension $\left(1 \times 10^{6}\right.$ conidia $\left.\mathrm{mL}^{-1}\right)$ in $2 \%$ agar-water medium, containing $2 \mathrm{~g}$ agar given $100 \mathrm{~mL}$ distilled water (w/v), then the culture was incubated for $1 \times 24$ hours and 2 x 24 hours. The culture was observed with a light microscope at $40 \mathrm{x}$ magnification to determine the number of germinated and non-germinated spores/conidia.

\section{Mass rearing of Spodoptera frugiperda}

Before the bioassay of endophytic fungi against larvae of Spodoptera frugiperda was conducted, the mass rearing of the test insects was carried out first. The insect used in this study was $S$. frugiperda taken from the farmers' maize farms. S. frugiperda was then taken to the laboratory to be maintained and mass-reared. The insect mass rearing modified the method of Herlinda et al. (2020b). In the laboratory, the $S$. frugiperda larvae were reared individually in a porous plastic cup $(\varnothing 6.5 \mathrm{~cm}$, height 4.6 $\mathrm{cm})$. In the cup, the maize leaves $(2 \mathrm{~cm} \times 5 \mathrm{~cm})$ were added to feed the larvae and the leaves were replaced every day with fresh new ones. When the last instar larvae got into the pupae stage, they were transferred to a plastic container $(\varnothing 15 \mathrm{~cm}$, height $25 \mathrm{~cm})$ whose bottom was given sterile soil ( $5 \mathrm{~cm}$ in thickness). The container containing the pupae was placed in a gauze cage $\left(30 \times 30 \times 30 \mathrm{~cm}^{3}\right)$, and in the gauze cage, there were 10 maize leaves provided for laying eggs and replaced every day. The egg clutch that the female adults laid on the surface of the maize leaves were moved into the container containing kale leaves (Ipomoea aquatica) used to feed the first instar larvae. After the first instar molting, the second instar larvae up to the last instar were fed with young maize leaves and maintained individually in a porous plastic cup $(\varnothing 6.5 \mathrm{~cm}$, height 4.6 $\mathrm{cm}$ ) because the second instar and so on were cannibalistic. The mass-rearing was carried out until getting the thirdgeneration culture. The second instar larvae aged 1 day were used for the bioassay.

\section{The bioassay of endophytic fungi against larvae of Spodoptera frugiperda}

Only the fungal isolates proven to be endophytic were tested for their pathogenicity against the second instar larvae of S. frugiperda. The bioassay of endophytic fungi against $S$. frugiperda larvae followed the method of Ramirez-Rodriguez and Sánchez-Peña (2016). The endophytic fungi were first propagated in PDA media. The endophytic fungi aged 7 days were made suspension with a density of $1 \times 10^{6}$ conidia $\mathrm{mL}^{-1}$. Before dropping the fungi suspension, the larvae were fasted for 2 hours and weighed using the portable jewelry scale (capacity $30 \mathrm{~g} \mathrm{x} 0.01 \mathrm{~g}$ ). Then, $1 \mathrm{~mL}^{-1}$ of the fungus suspension was dripped topically to wet $25 \mathrm{~S}$. frugiperda larvae, while the control ones were only dropped $1 \mathrm{~mL}^{-1}$ of the distilled water. This experiment was designed using completely randomized designs with treatments of isolates, three replications per treatment, and 25 larvae per replication. Furthermore, the larvae were put individually into a porous plastic cup $(\varnothing$ $6.5 \mathrm{~cm}$, height $4.6 \mathrm{~cm}$ ) and fed with maize leaves measuring $2 \times 5 \mathrm{~cm}^{2}$ per day per larvae. To measure the percentage of foliar damage caused by the larvae of $S$. frugiperda, the bioleaf application by Machado et al. (2016) was used. Each day the dead larvae were recorded and carried out for 12 days based on the previous studies by Herlinda et al. (2020b) and the dead larvae were grown in the agar-water medium to prove infection by the endophytic fungus. The number of larvae becoming pupae and adults that emerged was also counted. The number of dead larvae was used to calculate mortality, the Median Lethal Time $\left(\mathrm{LT}_{50}\right)$, and the $95 \%$ Lethal Time (LT 95$)$. The maize leaf area has eaten, fecal weight, and bodyweight of the larvae were measured daily from the first to the 12 th day.

\section{Data analysis}

The difference in larvae weight data and area of the leaves eaten and feces produced every day among the treatments (isolates), as well as mortality and time of death (the $\mathrm{LT}_{50}$ and $\mathrm{LT}_{95}$ ) larvae of $S$. frugiperda, the percentage of larvae becoming pupae and adults emerged, were analyzed using analysis of variance (ANOVA). The Tukey's Honestly Significant Difference (HSD) test (Tukey's test) was employed to test for a significant difference among the treatments at $\mathrm{P}=0.05$. The $\mathrm{LT}_{50}$ and $\mathrm{LT}_{95}$ values were calculated using the probit analysis. The data were all calculated using software of SAS University Edition 2.7 9.4 M5.

\section{RESULTS AND DISCUSSION}

\section{Endophytic fungi and their colonization on maize tissues}

Of the 52 isolates of fungi obtained from the roots of maize, banana and vegetables (chili) around the maize ecosystem, there were only eight isolates confirmed as the endophytic fungi (Table 1). The endophytic fungi were evidenced by the entry of the fungal tissue in the form of mycelia which grew to fill the plant tissue. The results of detection of fungal colonization in maize tissues showed differences from the controls (Figure 1). There was no colonization of endophytic fungi found in the untreated control plants. The plant tissue colonized by the endophytic fungi showed that mycelia grew to fill the plant tissue, while the control plant tissue was clean and no mycelium. The plants colonized by the endophytic fungi also showed a difference compared to the control plants (Figure 2), the inoculated plants tended to be taller with more roots and longer than the control plants.

The colony morphology of the eight isolates of the endophytic fungi showed different colors (Figure 3) and so did the morphology of hyphae and conidia, each isolate 
showing its own characteristics (Figure 4). The morphology of the $\mathrm{JgCrJr}$ and $\mathrm{JgSPK}$ isolates showed similarities, namely their colony was white, white hyphae, and mycelia, and the conidia were globose and nonseptation. However, the conidia of $\mathrm{JgCrJr}$ isolate was 2.21 x $2.80 \mu \mathrm{m}$ diameter and $3.07 \mu \mathrm{m}$ long, whereas the conidia of JgSPK isolate was $2.41 \times 2.97 \mu \mathrm{m}$ diameter and $3.07 \mu \mathrm{m}$ long. The genus of $\mathrm{JgCrJr}$ and JgSPK isolates was Beauveria sp. The PsgTjPr and JgByU isolates had black colony, black hyphae, and mycelia, and the non-septate globose-shaped conidia were $2.27 \mu \mathrm{m}$ long. So, the PsgTjPr and JgByU isolates were Aspergillus sp. The colony of JgPwSr isolates were green, and had green hyphae and mycelia. The $\mathrm{JgPwSr}$ conidia were non-septate globose with a length of $2.49 \mu \mathrm{m}$ and attached to phialides and the phialides adhered to vesicles. The genus of JgPwSr isolate was also Aspergillus sp. The $\mathrm{JgTgSr}$ and CMTjP isolates had a black colony, black hyphae and mycelia, and two septated boomerang-shaped conidia. Yet, the length of the $\mathrm{JgTgSr}$ conidia $(6.23 \mu \mathrm{m})$ was smaller than that of the CMTjP conidia $(10.51 \mu \mathrm{m})$. On the basis of the isolated morphological characters, the genus of the $\mathrm{JgTgSr}$ and CMTjP isolates was Curvularia sp. The JgTjPr isolate had purple colony, purple hyphae and mycelia, and the conidia had D-shape (asymmetric/elliptical), non-septate with a length of $3.96 \mu \mathrm{m}$. The genus of JgTjPr isolate was Chaetomium sp. So, the genus of the eight isolates of the endophytic fungi was Aspergillus sp., Beauveria sp., Chaetomium sp., and Curvularia sp.

Table 1. Species and isolates of endophytic fungi found from maize, banana, and chili in South Sumatra, Indonesia

\begin{tabular}{|c|c|c|c|c|c|c|}
\hline District/City & Village & $\begin{array}{l}\text { Crop } \\
\text { plants }\end{array}$ & Fungal species & Isolate codes & Soil pH & Altitude (m) \\
\hline Pagar Alam & Curup Jare & Maize & Beauveria sp. & $\mathrm{JgCrJr}$ & 6.2 & 806.7 \\
\hline Pagar Alam & Simpang Padang Karet & Maize & Beauveria sp. & JgSPK & 6.4 & 797.7 \\
\hline Ogan Ilir & Tanjung Pering & Banana & Aspergillus sp. & PsgTjPr & 7.0 & 36.00 \\
\hline Banyuasin & Banyu Urip & Maize & Aspergillus sp. & JgByU & 6.8 & 13.00 \\
\hline Banyuasin & Purwosari & Maize & Aspergillus sp. & $\mathrm{JgPwSr}$ & 5.5 & 15.00 \\
\hline Banyuasin & Telang Sari & Maize & Curvularia sp. & JgTgSr & 6.2 & 15.00 \\
\hline Pagar Alam & Tanjung Payang & Chili & Curvularia sp. & CMTjP & 6.0 & 689.6 \\
\hline Ogan Ilir & Tanjung Pering & Maize & Chaetomium sp. & JgTjPr & 6.4 & 36.00 \\
\hline
\end{tabular}

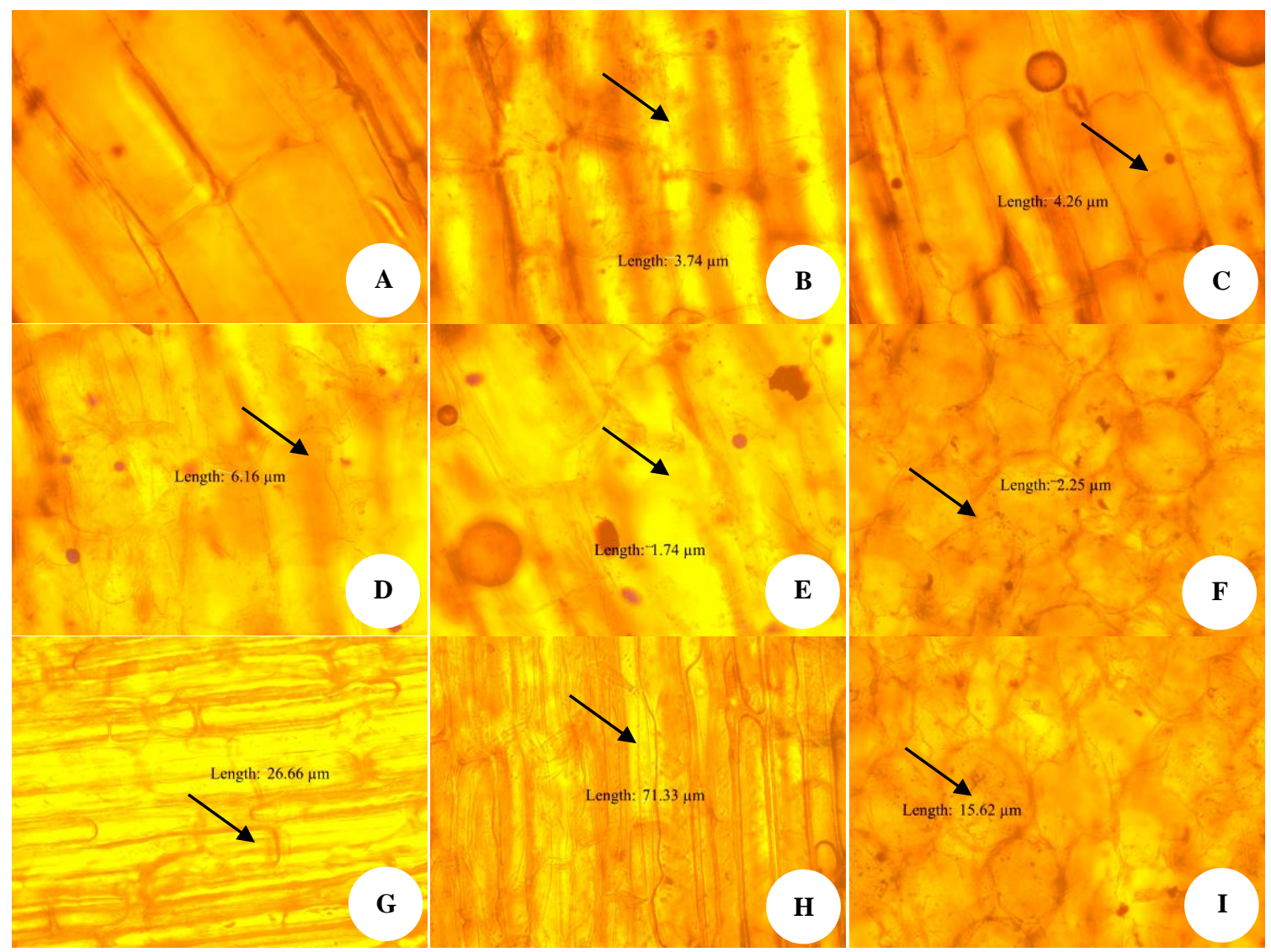

Figure 1. Ten-day maize tissues colonized by endophytic fungi: Control (A), and isolate of JgCrJr (B), JgSPK (C), PsgTjPr (D), JgByU (E), JgPwSr (F), JgTgSr (G), CMTjP (H), and JgTjPr (I) 
The conidia density of the eight isolates of the endophytic fungus did not show a significant difference among the isolates (Table 2). Nevertheless, the viability of conidia incubated either 1 × 24 hours or 2 x 24 hours showed a significant difference among the isolates. The conidial viability increased after the incubation of $2 \times 24$ hours. The highest conidia viability was found in JgSPK isolate (Beauveria sp.), while the lowest was in $\mathrm{JgTgSr}$ isolate (Curvularia sp.).

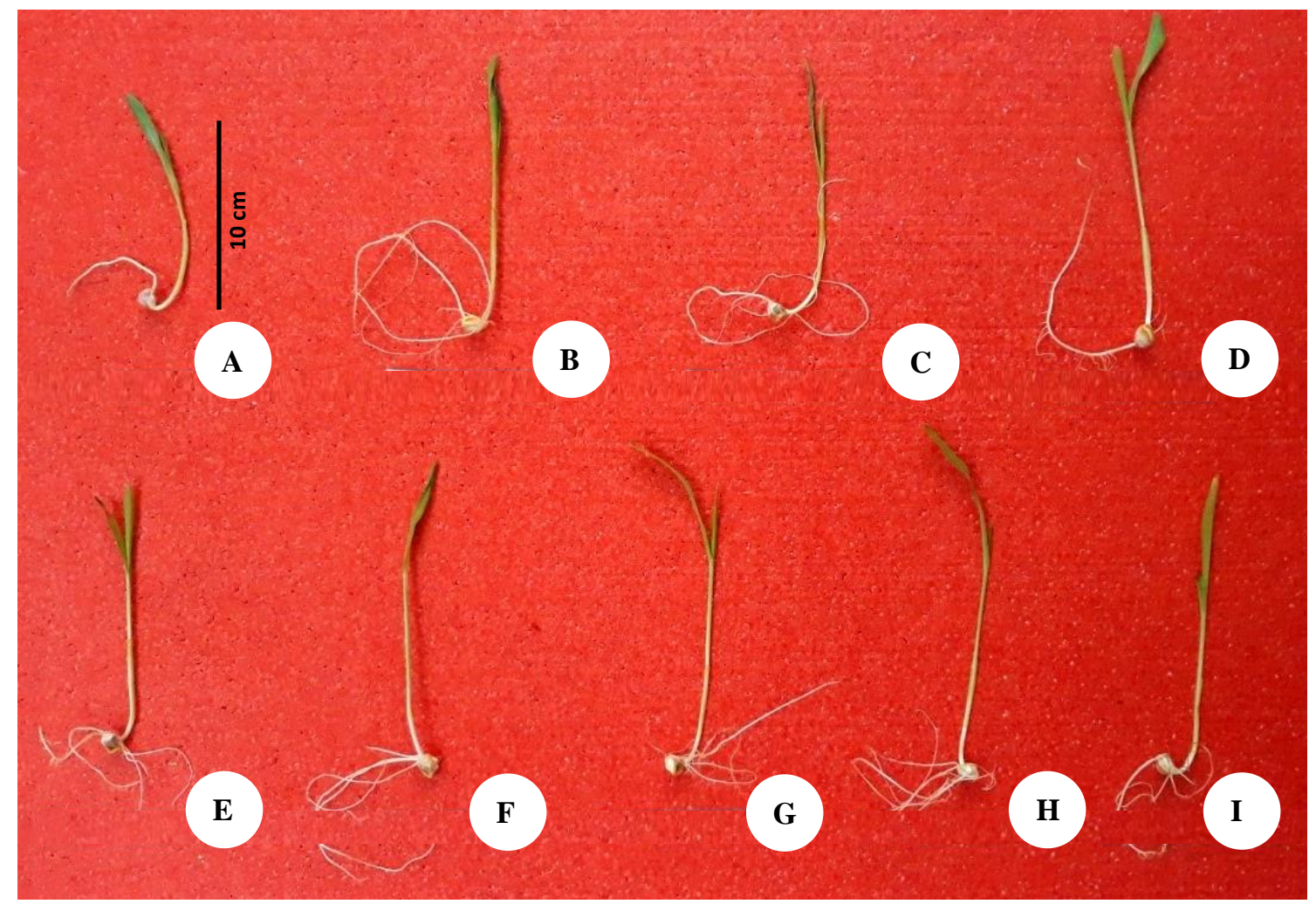

Figure 2. Ten-day maize plants treated with endophytic fungi $\left(1 \times 10^{6}\right.$ conidia $\left.\mathrm{mL}^{-1}\right)$ : Control (A), and isolate of $\mathrm{JgCrJr}(\mathrm{B}), \mathrm{JgSPK}(\mathrm{C})$, PsgTjPr (D), JgByU (E), JgPwSr (F), JgTgSr (G), CMTjP (H), and JgTjPr (I).

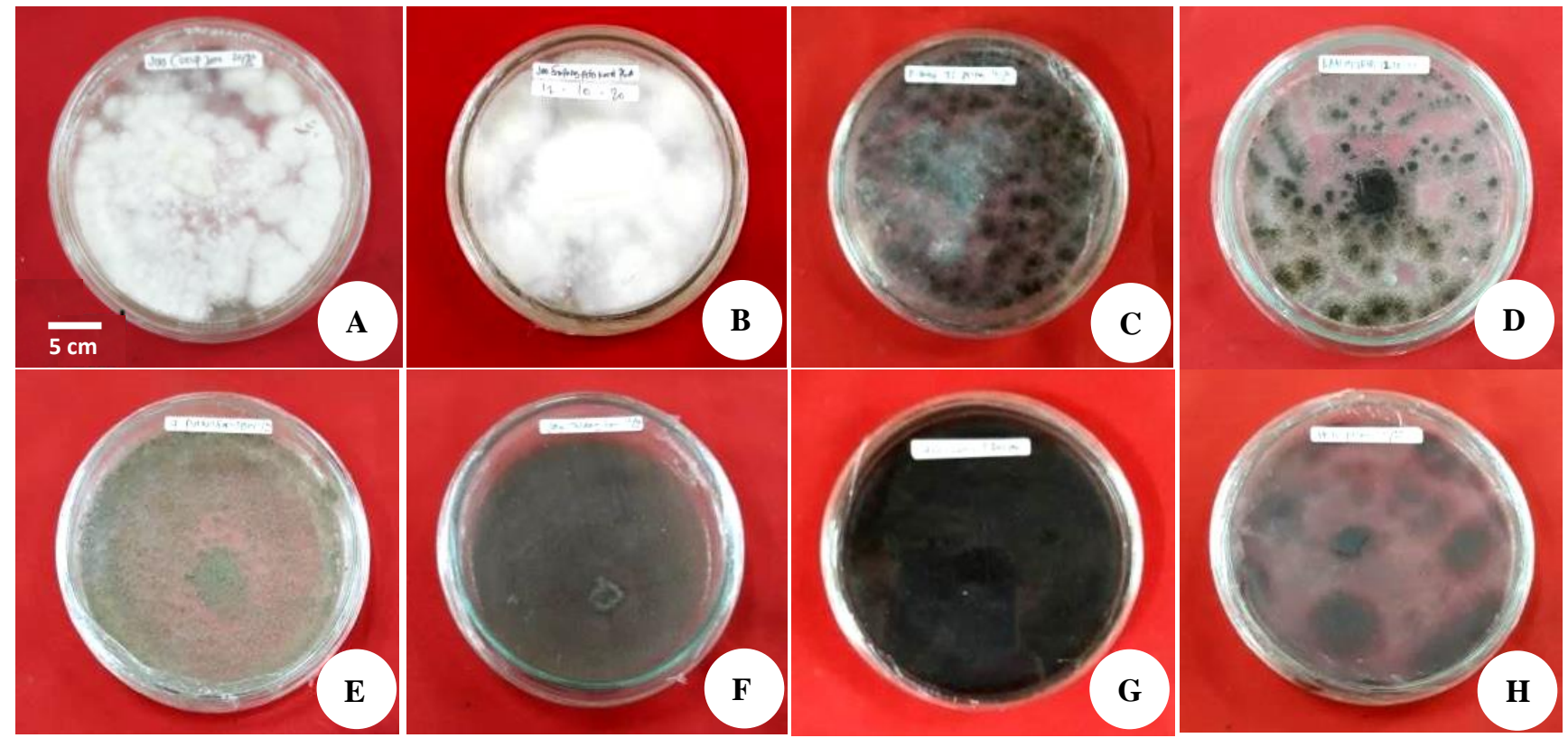

Figure 3. Colony morphology of of endophytic fungi cultured on PDA media: JgCrJr (A), JgSPK (B), PsgTjPr (C), JgByU (D), JgPwSr (E), $\operatorname{JgTgSr}(\mathrm{F}), \mathrm{CMTjP}(\mathrm{G})$, and $\operatorname{JgTj} \operatorname{Pr}(\mathrm{H})$ 


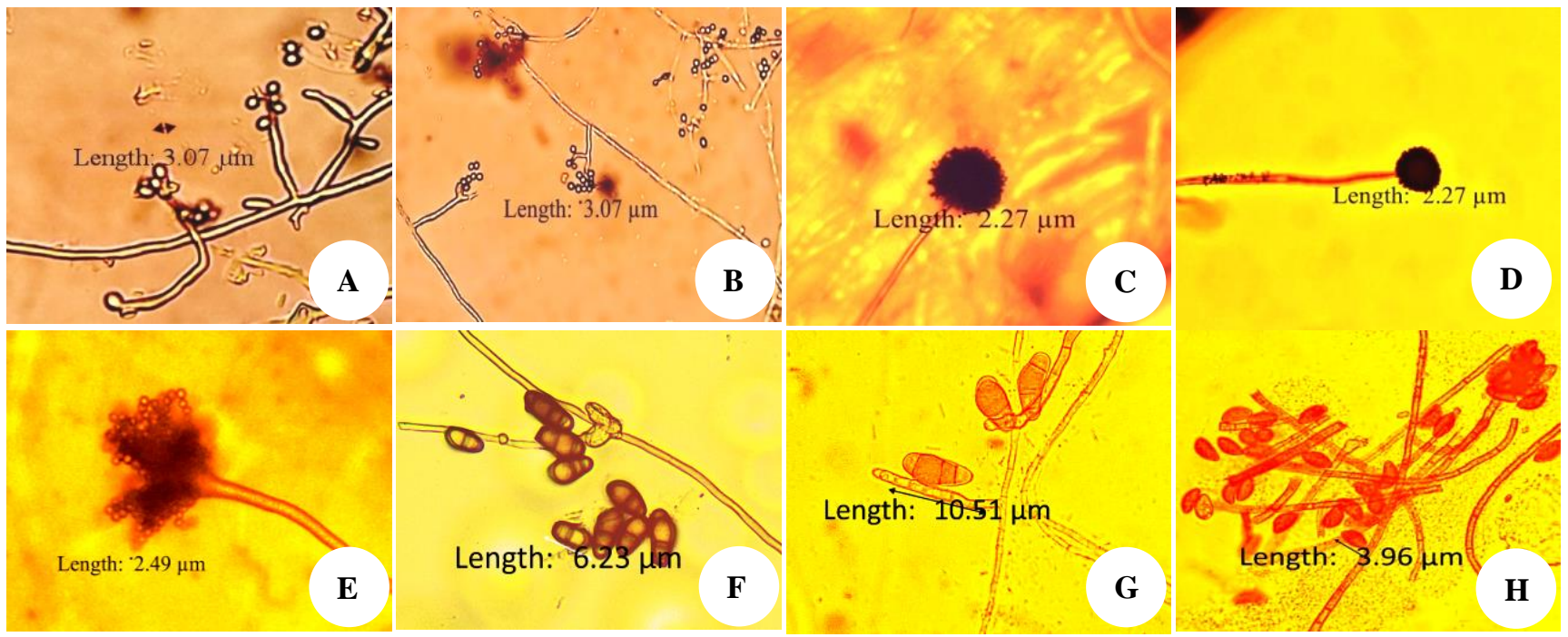

Figure 4. Conidial and hyphal morphology of endophytic fungi: $\mathrm{JgCrJr}(\mathrm{A}), \mathrm{JgSPK}(\mathrm{B}), \operatorname{PsgTjPr}(\mathrm{C}), \mathrm{JgByU}(\mathrm{D}), \mathrm{JgPwSr}(\mathrm{E}), \mathrm{JgTgSr}$ (F), $\operatorname{CMTjP}(\mathrm{G})$, and $\operatorname{JgTj} \operatorname{Pr}(\mathrm{H})$

Table 2. Mean of conidial density and viability of endophytic fungi

\begin{tabular}{|c|c|c|c|c|}
\hline \multirow{2}{*}{ Fungal species } & \multirow{2}{*}{ Isolate codes } & \multirow{2}{*}{$\begin{array}{c}\text { Conidial density } \\
\left(1 \times 10^{8} \text { conidia } \mathrm{L}^{-1}\right)\end{array}$} & \multicolumn{2}{|c|}{ Conidial viability (\%) } \\
\hline & & & 24-hour culture & 48-hour culture \\
\hline Beauveria sp. & $\mathrm{JgCrJr}$ & $4.17 \pm 0.24$ & $55.17 \pm 4.93^{\mathrm{bc}}$ & $55.66 \pm 5.05^{\mathrm{bc}}$ \\
\hline Beauveria sp. & JgSPK & $3.19 \pm 0.58$ & $58.69 \pm 0.89^{c}$ & $61.87 \pm 0.98^{c}$ \\
\hline Aspergillus sp. & PsgTjPr & $1.57 \pm 0.10$ & $46.58 \pm 2.15^{\mathrm{abc}}$ & $48.84 \pm 2.88^{\mathrm{ab}}$ \\
\hline Aspergillus sp. & JgByU & $3.36 \pm 0.18$ & $45.04 \pm 2.73^{\mathrm{ab}}$ & $50.95 \pm 2.77^{\mathrm{abc}}$ \\
\hline Aspergillus sp. & JgPwSr & $1.69 \pm 0.30$ & $41.36 \pm 3.85^{\mathrm{ab}}$ & $47.71 \pm 0.21^{\mathrm{ab}}$ \\
\hline Curvularia sp. & $\mathrm{JgTgSr}$ & $3.74 \pm 0.38$ & $38.98 \pm 3.25^{\mathrm{a}}$ & $42.73 \pm 2.53^{\mathrm{a}}$ \\
\hline Curvularia sp. & CMTjP & $3.94 \pm 0.42$ & $42.03 \pm 3.14^{\mathrm{ab}}$ & $51.18 \pm 1.85^{\mathrm{ab}}$ \\
\hline Chaetomium sp. & JgTjPr & $3.22 \pm 0.30$ & $39.50 \pm 0.15^{\mathrm{a}}$ & $43.14 \pm 7.53^{\mathrm{a}}$ \\
\hline F-value & & $0.06^{\mathrm{ns}}$ & $4.91^{*}$ & $5.90^{*}$ \\
\hline P-value & & 1.00 & 0.00 & 0.00 \\
\hline HSD value & & 3.06 & 9.02 & 7.12 \\
\hline
\end{tabular}

Note: $\mathrm{ns}=$ not significantly different; values within a column followed by the same letters were not significantly different at $\mathrm{P}<0.05$ according to Tukey's HSD test.

Table 3. Leaf area eaten by Spodoptera frugiperda larvae treated with of endophytic fungi $\left(1 \times 10^{6}{\left.\text { conidia } \mathrm{mL}^{-1}\right)}^{-1}\right.$

\begin{tabular}{|c|c|c|c|c|c|c|c|c|c|c|c|c|}
\hline \multirow{2}{*}{ Isolates } & \multicolumn{12}{|c|}{ Mean of leaf area eaten by larvae $\left(\mathrm{cm}^{2}\right.$ larvae ${ }^{-1}$ day $\left.^{-1}\right)$ during 12 days of observation } \\
\hline & 1 & 2 & 3 & 4 & 5 & 6 & 7 & 8 & 9 & 10 & 11 & 12 \\
\hline Control & $4.60^{b}$ & 4.53 & 7.73 & 8.29 & 8.58 & $8.83^{\mathrm{c}}$ & $8.74^{b}$ & $8.83^{\mathrm{b}}$ & $8.85^{\mathrm{b}}$ & 8.41 & 8.86 & $8.99^{b}$ \\
\hline $\mathrm{JgCrJr}$ & $3.62^{\mathrm{ab}}$ & 4.18 & 5.30 & 6.11 & 7.42 & $8.12^{\mathrm{bc}}$ & $7.97^{\mathrm{ab}}$ & $7.67^{\mathrm{ab}}$ & $7.07^{\mathrm{a}}$ & 6.64 & 6.32 & $5.77^{\mathrm{a}}$ \\
\hline JgSPK & $3.36^{\mathrm{a}}$ & 4.12 & 5.11 & 6.34 & 6.91 & $7.31^{\mathrm{abc}}$ & $7.36^{\mathrm{ab}}$ & $7.14^{\mathrm{ab}}$ & $7.13^{\mathrm{a}}$ & 7.57 & 7.11 & $6.00^{\mathrm{a}}$ \\
\hline PsgTjPr & $3.78^{\mathrm{ab}}$ & 4.35 & 6.21 & 7.98 & 7.67 & $7.36^{\mathrm{abc}}$ & $7.47^{\mathrm{ab}}$ & $7.38^{\mathrm{ab}}$ & $7.36^{\mathrm{ab}}$ & 7.36 & 6.73 & $6.21^{\mathrm{a}}$ \\
\hline JgByU & $3.78^{\mathrm{ab}}$ & 4.15 & 5.25 & 6.27 & 7.58 & $7.53^{\mathrm{abc}}$ & $7.80^{\mathrm{ab}}$ & $7.72^{\mathrm{ab}}$ & $7.67^{\mathrm{ab}}$ & 7.86 & 7.56 & $7.05^{\mathrm{ab}}$ \\
\hline JgPwSr & $3.76^{\mathrm{ab}}$ & 4.43 & 6.17 & 6.88 & 7.79 & $8.12^{\mathrm{bc}}$ & $8.07^{\mathrm{ab}}$ & $7.49^{\mathrm{ab}}$ & $7.27^{\mathrm{ab}}$ & 7.14 & 6.95 & $6.45^{\mathrm{a}}$ \\
\hline $\mathrm{JgTgSr}$ & $3.52^{\mathrm{a}}$ & 3.88 & 7.13 & 7.72 & 6.86 & $6.52^{\mathrm{ab}}$ & $7.96^{\mathrm{ab}}$ & $7.03^{\mathrm{ab}}$ & $6.67^{\mathrm{a}}$ & 6.69 & 7.44 & $6.53^{\mathrm{a}}$ \\
\hline CMTjP & $3.62^{\mathrm{ab}}$ & 3.98 & 6.40 & 7.89 & 6.88 & $6.33^{\mathrm{a}}$ & $6.73^{\mathrm{a}}$ & $6.73^{\mathrm{a}}$ & $6.48^{\mathrm{a}}$ & 6.87 & 7.42 & $6.80^{\mathrm{ab}}$ \\
\hline JgTjPr & $3.66^{\mathrm{ab}}$ & 4.24 & 5.82 & 6.53 & 6.78 & $7.21^{\mathrm{abc}}$ & $6.78^{\mathrm{ab}}$ & $7.31^{\mathrm{ab}}$ & $7.92^{\mathrm{ab}}$ & 7.50 & 7.52 & $7.28^{\mathrm{ab}}$ \\
\hline F-value & $2.96^{*}$ & $1.69^{\mathrm{ns}}$ & $1.14^{\mathrm{ns}}$ & $0.67^{\mathrm{ns}}$ & $0.63^{\mathrm{ns}}$ & $5.01^{*}$ & $3.08^{*}$ & $2.59^{*}$ & $5.25^{\mathrm{ns}}$ & $1.79^{\text {ns }}$ & $2.30^{\mathrm{ns}}$ & $4.94^{*}$ \\
\hline P-value & 0.03 & 0.17 & 0.39 & 0.71 & 0.74 & 0.00 & 0.02 & 0.04 & 0.00 & 0.14 & 0.07 & 0.00 \\
\hline HSD value & 0.23 & 0.18 & 0.77 & 0.90 & 0.67 & 0.31 & 0.32 & 0.32 & 0.27 & 0.38 & 0.41 & 0.38 \\
\hline
\end{tabular}

Note: $\mathrm{ns}=$ not significantly different; ${ }^{*}=$ significantly different; values within a column followed by the same letters were not significantly different at $\mathrm{P}<0.05$ according to Tukey's HSD test

The endophytic fungi pathogenicity against Spodoptera frugiperda larvae

The results of the measurement of leaf area eaten by the larvae dripped with the endophytic fungi suspension $(1 \mathrm{x}$ $10^{6}$ conidia $\mathrm{mL}^{-1}$ ) and the control (untreated) on the first day showed significant differences. In the control, the larvae ate the most maize leaves (Table 3). On the second to the fifth days, the leaf area eaten by the larvae from all treatments was not significantly different, while on the sixth to 12 th days, the leaf area eaten by the control larvae 
was wider and tended to be significantly different from that eaten by the larvae being already treated with the endophytic fungi. Consequently, the treated larvae experienced a significant decrease in appetite compared to that of the control. The symptoms of leaves eaten by the larvae treated with the fungus and those eaten by the control also showed significant differences (Figure 5).

The decrease in appetite in the larvae treated with the endophytic fungi was followed by a decrease in their body weight. On the second day, the weight loss of the treated larvae was significant compared to that of the control, while on the next day, the weight of the larvae among the treatments was not significantly different (Table 4). The fecal weight produced by the treated and untreated larvae tended to show a significant difference. The stool weight produced by the treated larvae tended to be heavier than that produced by the untreated larvae (control) (Table 5). This phenomenon is interesting because generally the normal larvae, which eat a lot, produce a lot of feces, but in this experiment, the result showed the opposite.

Of the eight endophytic fungal isolates found, the most pathogenic $\mathrm{JgCrJr}$ isolate (Beauveria sp.) resulted in $29.33 \%$ larval mortality with $\mathrm{LT}_{50}$ for 17.40 days, followed by JgSPK isolate (Beauveria sp.) (26.67\% mortality) with $\mathrm{LT}_{50}$ for 15 days (Table 6). The mortality caused by these two isolates from the beginning of observation to the last day was always higher; the isolate with the lowest ability to cause mortality was $\mathrm{JgTgSr}$ (Curvularia sp.) (Figure 6). Besides Beauveria sp., Aspergillus sp., Chaetomium sp., and Curvularia sp. were also able to cause mortality of $S$. frugiperda larvae. In Indonesia, first report of Aspergillus sp., Chaetomium sp., and Curvularia sp. have insecticidal activity against $S$. frugiperda larvae. The isolate that had the highest reduction in the emergence of adults occurred in $\mathrm{JgCrJr}$ isolate (Beauveria sp.), causing only $56 \%$ of $S$. frugiperda adults to emerge (Table 7). Therefore, the isolate $\mathrm{JgCrJr}$ (Beauveria sp.) could reduce the adult emergence of $S$. frugiperda by $44 \%$.

The treated larvae exhibited distinctive symptoms that distinguished them from the healthy larvae (Figure 7). The healthy larvae were longer and bigger, and had flexible movements and a tight body, while the larvae that were sick due to being infected with the endophytic fungi were stiff, its body was smaller, shrivels, hardens like a mummy, and over time the body changes color to black but did not smell. The dead larvae were grown in the agar-water medium and their integument grew mycelia and conidia that covered the cadaver. Apart from the larval mortality, the endophytic fungus caused the pupae and adults to be abnormal and malformed (Figures 8 and 9). The abnormal pupae were thinner, bent, shriveled wings, and darker in color, and when their body was touched they did not move. The abnormal adults had folded and smaller wings than those of the normal adults.

Table 4. Weight of Spodoptera frugiperda larvae treated with endophytic fungi $\left(1 \times 10^{6}\right.$ conidia $\left.\mathrm{mL}^{-1}\right)$

\begin{tabular}{|c|c|c|c|c|c|c|c|c|c|c|c|c|}
\hline \multirow[t]{2}{*}{ Isolates } & \multicolumn{12}{|c|}{ Mean of larvae weight $\left(\mathrm{mg} \mathrm{larvae}^{-1}\right)$ during 12 days observation } \\
\hline & 1 & 3 & 3 & 4 & 5 & 6 & 7 & 8 & 9 & 10 & 11 & 12 \\
\hline Control & 22.99 & $74.45^{\mathrm{b}}$ & 49.16 & 69.65 & 97.89 & 124.53 & 129.27 & 136.17 & 173.73 & 190.91 & 207.07 & 217.27 \\
\hline $\mathrm{JgCrJr}$ & 23.72 & $38.67^{\mathrm{ab}}$ & 61.24 & 66.11 & 83.40 & 102.58 & 125.08 & 137.88 & 161.84 & 168.24 & 181.25 & 171.60 \\
\hline JgSPK & 22.09 & $25.57^{\mathrm{a}}$ & 42.17 & 74.95 & 87.53 & 110.08 & 115.04 & 134.66 & 173.90 & 197.97 & 195.24 & 183.52 \\
\hline PsgTjPr & 28.92 & $45.49^{\mathrm{ab}}$ & 44.87 & 53.95 & 81.57 & 90.41 & 104.52 & 127.67 & 160.22 & 192.28 & 179.91 & 180.66 \\
\hline $\mathrm{JgByU}$ & 26.63 & $45.45^{\mathrm{ab}}$ & 57.12 & 68.35 & 74.09 & 88.80 & 115.26 & 132.24 & 144.85 & 157.14 & 161.54 & 168.66 \\
\hline $\mathrm{JgPwSr}$ & 15.13 & $53.59^{\mathrm{ab}}$ & 65.47 & 67.29 & 93.61 & 106.29 & 124.06 & 145.27 & 176.09 & 192.37 & 184.76 & 183.23 \\
\hline $\mathrm{JgTgSr}$ & 19.29 & $34.12^{\mathrm{a}}$ & 52.73 & 56.47 & 65.89 & 75.23 & 103.57 & 126.66 & 146.83 & 162.20 & 177.46 & 172.63 \\
\hline СMTjP & 25.31 & $32.15^{\mathrm{a}}$ & 39.76 & 56.37 & 65.97 & 87.10 & 119.70 & 137.81 & 176.33 & 195.52 & 188.19 & 176.03 \\
\hline JgTjPr & 24.85 & $35.51^{\mathrm{a}}$ & 48.48 & 60.21 & 80.51 & 95.32 & 126.71 & 139.42 & 197.67 & 179.91 & 186.21 & 185.67 \\
\hline F-value & $0.79^{\text {ns }}$ & $4.33^{*}$ & $1.61^{\mathrm{ns}}$ & $0.41^{\mathrm{ns}}$ & $1.28^{\mathrm{ns}}$ & $2.18^{\mathrm{ns}}$ & $0.69^{\text {ns }}$ & $0.18^{\mathrm{ns}}$ & $1.33^{\mathrm{ns}}$ & $1.64^{\mathrm{ns}}$ & $0.75^{\mathrm{ns}}$ & $0.99^{\text {ns }}$ \\
\hline $\mathrm{P}$ value & 0.62 & 0.00 & 0.19 & 0.90 & 0.31 & 0.08 & 0.70 & 0.99 & 0.29 & 0.18 & 0.65 & 0.47 \\
\hline HSD value & 2.59 & 2.54 & 2.34 & 3.61 & 2.73 & 2.49 & 2.56 & 2.86 & 2.72 & 2.30 & 2.67 & 2.61 \\
\hline
\end{tabular}

Note: ns = not significantly different; * = significantly different; values within a column followed by the same letter were not significantly different at $\mathrm{P}<0.05$ according to Tukey's HSD test

Table 5. Fecal weight produced by Spodoptera frugiperda larvae treated with endophytic fungi $\left(1 \times 10^{6}{\left.\text { conidia } \mathrm{mL}^{-1}\right)}^{-1}\right.$

\begin{tabular}{|c|c|c|c|c|c|c|c|c|c|c|c|c|}
\hline \multirow[t]{2}{*}{ Isolates } & \multicolumn{12}{|c|}{ Mean of larvae fecal weight $\left(\mathrm{mg} \mathrm{larvae}^{-1}\right.$ day $\left.^{-1}\right)$ during 12 days of observation } \\
\hline & 1 & 3 & 3 & 4 & 5 & 6 & 7 & 8 & 9 & 10 & 11 & 12 \\
\hline Control & $11.67^{\mathrm{ab}}$ & $15.67^{\mathrm{ab}}$ & 17.67 & $20.67^{\mathrm{a}}$ & $25.33^{\mathrm{a}}$ & 28.00 & 31.33 & $35.00^{\mathrm{a}}$ & $38.00^{\mathrm{a}}$ & 41.33 & 47.80 & $53.33^{\mathrm{c}}$ \\
\hline $\mathrm{JgCrJr}$ & $.22^{\mathrm{a}}$ & $7.21^{\mathrm{a}}$ & 25.59 & $55.35^{\mathrm{c}}$ & $71.60^{\mathrm{c}}$ & 14 & 73.47 & $64.62^{\mathrm{ab}}$ & $57.24^{\mathrm{b}}$ & 37 & 47.45 & $30.98^{\mathrm{ab}}$ \\
\hline JgSPK & $8.98^{\mathrm{ab}}$ & $13.58^{\mathrm{ab}}$ & 32.12 & $39.37^{b c}$ & $47.73^{\mathrm{abc}}$ & .06 & 59.15 & $71.79^{b}$ & $62.52^{\mathrm{b}}$ & 49 & 44.05 & $36.99^{\mathrm{abc}}$ \\
\hline PsgTjPr & $20.28^{\mathrm{b}}$ & $25.05^{\mathrm{bcd}}$ & 28.26 & $31.21^{\mathrm{ab}}$ & $43.59^{a b c}$ & 45.75 & 49.96 & $45.65^{\mathrm{ab}}$ & $41.91^{\mathrm{b}}$ & 63 & 38.34 & $35.09^{\mathrm{abc}}$ \\
\hline $\mathrm{JgByU}$ & $16.56^{\mathrm{ab}}$ & $21.39^{\mathrm{bcd}}$ & 31.55 & $37.65^{\mathrm{abc}}$ & $48.19^{\mathrm{abc}}$ & 51.45 & 55.68 & $63.66^{\mathrm{ab}}$ & $47.76^{\mathrm{b}}$ & 46.29 & 41.93 & $36.27^{\mathrm{abc}}$ \\
\hline JgPwSr & $21.13^{\mathrm{b}}$ & $32.60^{\mathrm{d}}$ & 43.62 & $46.10^{\mathrm{bc}}$ & $55.19^{\mathrm{bc}}$ & 55.89 & 54.37 & $57.60^{\mathrm{ab}}$ & $58.10^{\mathrm{b}}$ & 67 & 44.08 & $41.12^{\mathrm{bc}}$ \\
\hline $\mathrm{JgTgSr}$ & $.10^{\mathrm{ab}}$ & $17.60^{\mathrm{bc}}$ & 25.75 & $31.53^{\mathrm{ab}}$ & $35.00^{\mathrm{ab}}$ & 40.41 & 45.86 & $47.81^{\mathrm{ab}}$ & $40.65^{\mathrm{b}}$ & 33 & 33.79 & $21.57^{\mathrm{a}}$ \\
\hline CMTjP & $19.28^{\mathrm{ab}}$ & $34.39^{\mathrm{d}}$ & 41.87 & $40.89^{b c}$ & $43.51^{a b c}$ & 57.52 & 60.45 & $63.46^{\mathrm{ab}}$ & $60.74^{\mathrm{b}}$ & 54.64 & 46.32 & $38.63^{\mathrm{bc}}$ \\
\hline JgTjPr & $24.80^{\mathrm{b}}$ & $29.39^{\text {cd }}$ & 36.25 & $39.22^{\mathrm{bc}}$ & $47.26^{\mathrm{abc}}$ & 55.54 & 57.04 & $61.80^{\mathrm{ab}}$ & $60.66^{\mathrm{b}}$ & 55.00 & 45.02 & $40.77^{\mathrm{bc}}$ \\
\hline F-value & $3.74^{*}$ & $14.29^{*}$ & $2.50^{\mathrm{ns}}$ & $6.42^{*}$ & $4.16^{*}$ & $2.26^{\mathrm{ns}}$ & $1.72^{\mathrm{ns}}$ & $2.77^{*}$ & $3.86^{*}$ & $1.68^{\mathrm{ns}}$ & $1.41^{\mathrm{ns}}$ & $5.18^{*}$ \\
\hline P-value & 0.01 & 0.00 & 0.05 & 0.00 & 0.01 & 0.07 & 0.16 & 0.03 & 0.01 & 0.17 & 0.26 & 0.00 \\
\hline HSD value & 2.28 & 1.35 & 2.39 & 1.57 & 2.22 & 2.83 & 2.92 & 2.35 & 1.74 & 2.21 & 1.50 & 1.55 \\
\hline
\end{tabular}

Note: ns = not significantly different; * = significantly different; values within a column (the data of each isolate) followed by the same letter were not significantly different at $\mathrm{P}<0.05$ according to Tukey's HSD test 
Table 6. Mean of larvae mortality, $\mathrm{LT}_{50}$, and $\mathrm{LT}_{95}$ of Spodoptera frugiperda larvae treated with endophytic fungi $\left(1 \times 10^{6}\right.$ conidia $\mathrm{mL}^{-1}$ )

\begin{tabular}{|c|c|c|c|c|c|c|}
\hline Isolates & $\begin{array}{c}\text { Mortality } \pm \text { SE } \\
(\%)\end{array}$ & $\begin{array}{c}\mathbf{L T}_{50} \pm \mathrm{SE} \\
\text { (days) }\end{array}$ & $\begin{array}{c}\mathbf{L T}_{95} \pm \mathrm{SE} \\
\text { (days) }\end{array}$ & Isolates & $\begin{array}{l}\text { Mean of pupae } \\
\text { formation }(\%)\end{array}$ & $\begin{array}{c}\text { Mean of adults } \\
\text { emerged }(\%)\end{array}$ \\
\hline Control & $0.00 \pm 0.00^{\mathrm{a}}$ & - & - & Control & $100.00^{\mathrm{d}}$ & $100.00^{\mathrm{d}}$ \\
\hline $\mathrm{JgCrJr}$ & $29.33 \pm 3.53^{\mathrm{d}}$ & $17.40 \pm 1.37$ & $30.08 \pm 2.51$ & $\mathrm{JgCrJr}$ & $70.67^{\mathrm{a}}$ & $56.00^{\mathrm{a}}$ \\
\hline JgSPK & $26.67 \pm 3.53^{\mathrm{cd}}$ & $15.00 \pm 1.06$ & $27.69 \pm 2.20$ & JgSPK & $73.33^{\mathrm{ab}}$ & $60.00^{\mathrm{ab}}$ \\
\hline PsgTjPr & $18.67 \pm 3.53^{\mathrm{bcd}}$ & $17.94 \pm 0.68$ & $30.62 \pm 1.68$ & PsgTjPr & $81.33^{\mathrm{abc}}$ & $70.67^{\mathrm{abc}}$ \\
\hline JgByU & $9.33 \pm 3.53^{\mathrm{b}}$ & $23.66 \pm 3.01$ & $36.35 \pm 4.14$ & JgByU & $90.67^{c}$ & $80.00^{\mathrm{bc}}$ \\
\hline JgPwSr & $17.33 \pm 3.53^{\mathrm{bcd}}$ & $18.89 \pm 1.72$ & $31.58 \pm 2.84$ & $\mathrm{JgPwSr}$ & $82.67^{\mathrm{abc}}$ & $74.67^{\mathrm{abc}}$ \\
\hline JgTgSr & $9.33 \pm 1.33^{\mathrm{b}}$ & $22.12 \pm 2.15$ & $34.81 \pm 3.30$ & $\mathrm{JgTgSr}$ & $90.67^{c}$ & $84.00^{c}$ \\
\hline CMTjP & $12.00 \pm 2.31^{\mathrm{bc}}$ & $20.37 \pm 1.64$ & $33.06 \pm 2.75$ & CMTjP & $88.00^{\mathrm{bc}}$ & $80.00^{\mathrm{bc}}$ \\
\hline JgTjPr & $14.67 \pm 3.53^{\mathrm{bcd}}$ & $20.14 \pm 2.28$ & $32.82 \pm 3.14$ & $\mathrm{JgTjPr}$ & $85.33^{\mathrm{abc}}$ & $80.00^{\mathrm{bc}}$ \\
\hline F-value & $15.51^{*}$ & $2.13^{\mathrm{ns}}$ & $0.88^{\mathrm{ns}}$ & F-value & $16.03^{*}$ & $17.24^{*}$ \\
\hline P-value & 0.00 & 0.09 & 0.55 & $P$ value & 0.00 & 0.00 \\
\hline HSD value & 11.88 & 8.74 & 13.58 & HSD value & 11.88 & 14.29 \\
\hline
\end{tabular}

Note: ns = not significantly different; $*$ = significantly different; values within a column followed by the same letter were not significantly different at $\mathrm{P}<0.05$ according to Tukey's HSD test.
Table 7. Percentage of Spodoptera frugiperda pupae formation and adults emerged after their larvae treated with endophytic fungi $\left(1 \times 10^{6}\right.$ conidia $\left.\mathrm{mL}^{-1}\right)$
Note: ns = not significantly different; $*$ = significantly different; values within a column followed by the same letter were not significantly different at $\mathrm{P}<0.05$ according to Tukey's HSD test.

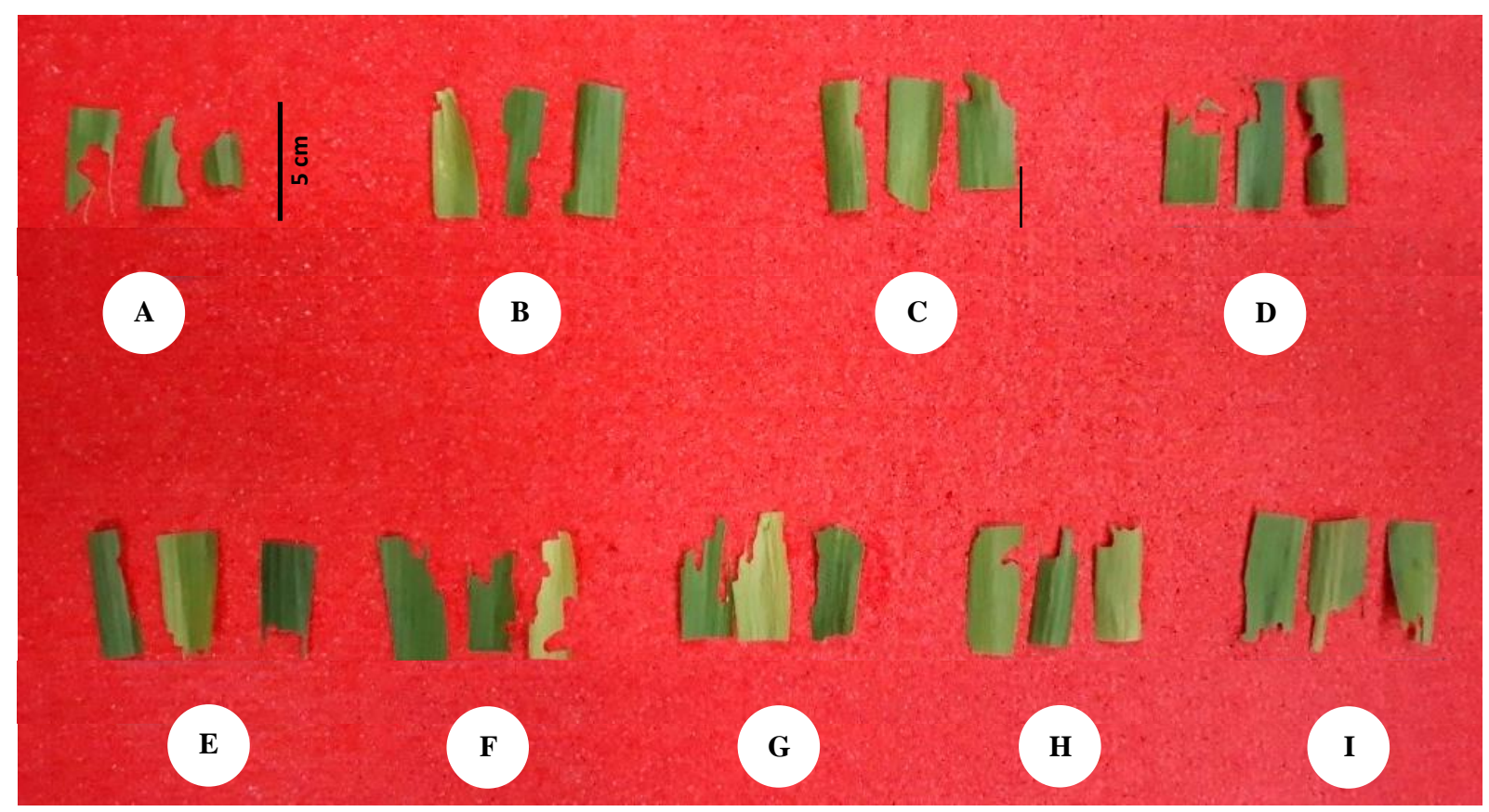

Figure 5. The symptoms on maize leaves eaten by Spodoptera frugiperda larvae treated with endophytic fungi $\left(1 \mathrm{x} 10^{6} \mathrm{conidia}^{-1}\right)$ : Control (A), JgCrJr (B), JgSPK (C), PsgTjPr (D), JgByU (E), JgPwSr (F), JgTgSr (G), CMTjP (H), and JgTjPr (I)

\section{Discussion}

Based on the morphological characteristics, the $\mathrm{JgCrJr}$ and JgSPK isolates belong to the genus of Beauveria sp. The PsgTjPr, JgByU, and JgPwSr isolates belong to the genus of Aspergillus sp. The JgTgSr and CMTjP isolates include in Curvularia sp. The genus of JgTjPr isolate is Chaetomium sp. The morphological characteristics of the four fungal genus match to description by Humber (2005) and El-Ghany (2015). All genus of the endophytic fungi found in this study have insecticidal activity against the $S$. frugiperda. . First report of Aspergillus sp., Chaetomium sp., and Curvularia sp. are pathogenic against $S$. frugiperda larvae. The endophytic Beauveria spp. have been shown to kill various species of the insect pests, such as Diaphorina citri (Bamisile et al. 2019), Trialeurodes vaporariorum (Barra-Bucarei et al. 2020) Wicklow et al. (2000) reported that Chaetomium sp. is pathogenic against Helicoverpa zea. Chaetomium globosum significantly inhibits the growth and reproduction of Myzus persicae (Qi et al. 2011). Aspergillus sp. and Curvularia sp. are opportunistic fungi that probably they display an important role in regulating insect populations (Assaf et al. 2011). 


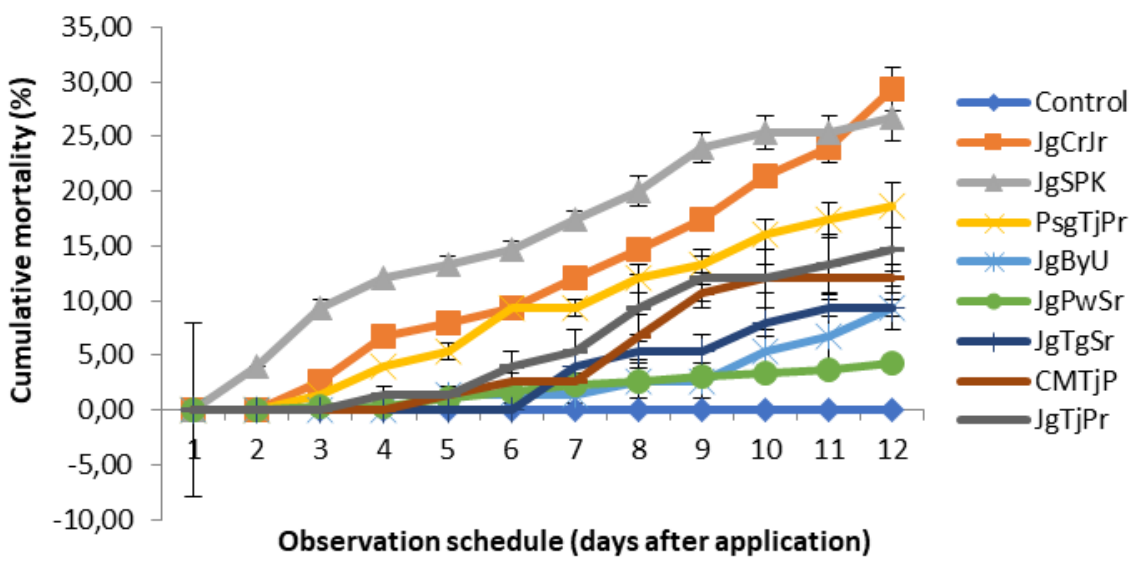

Figure 6. Cumulative mortality of Spodoptera frugiperda larvae treated with endophytic fungi $\left(1 \times 10^{6}\right.$ conidia $\left.\mathrm{mL}^{-1}\right)$ during $12 \mathrm{days}$ observation

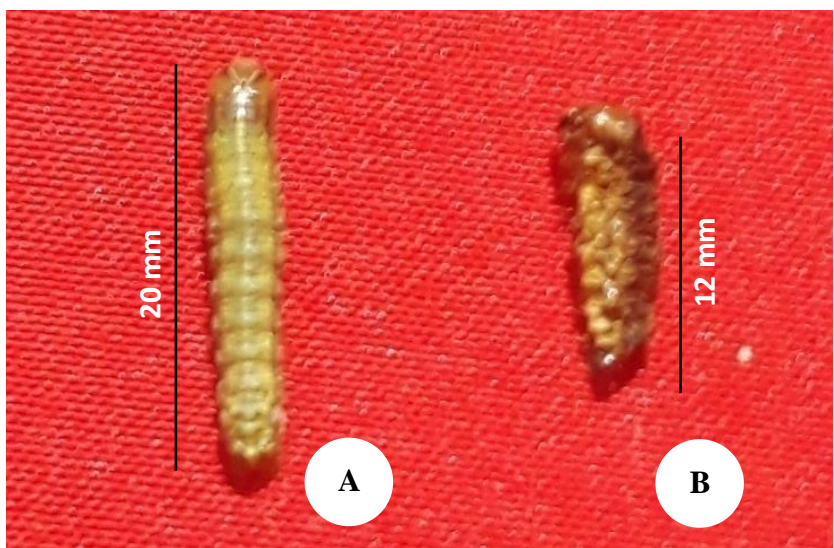

Figure 7. Morphology of Spodoptera frugiperda larvae: healthy larvae of control (A) and dead larvae infected by endophytic fungi (B)

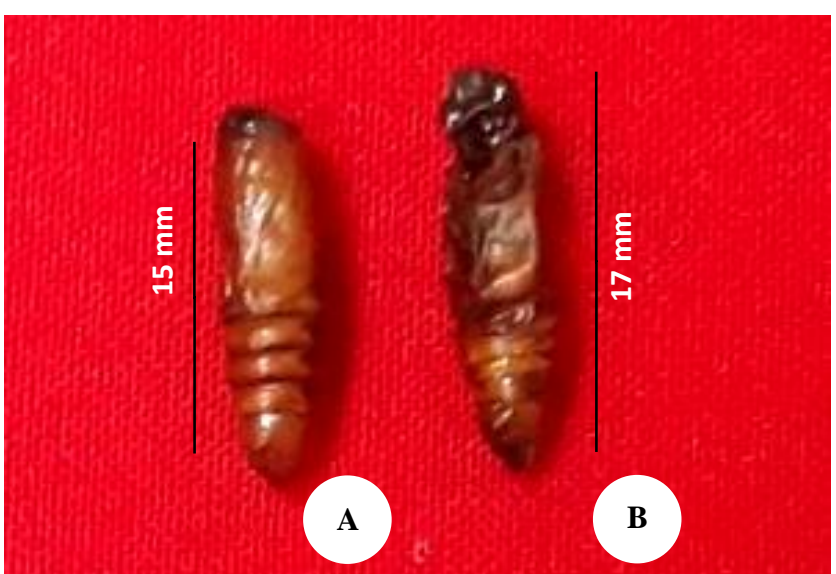

Figure 8. Morphology of Spodoptera frugiperda pupae: healthy pupae of control (A) and unhealthy with malformation pupae infected by endophytic fungi (B)

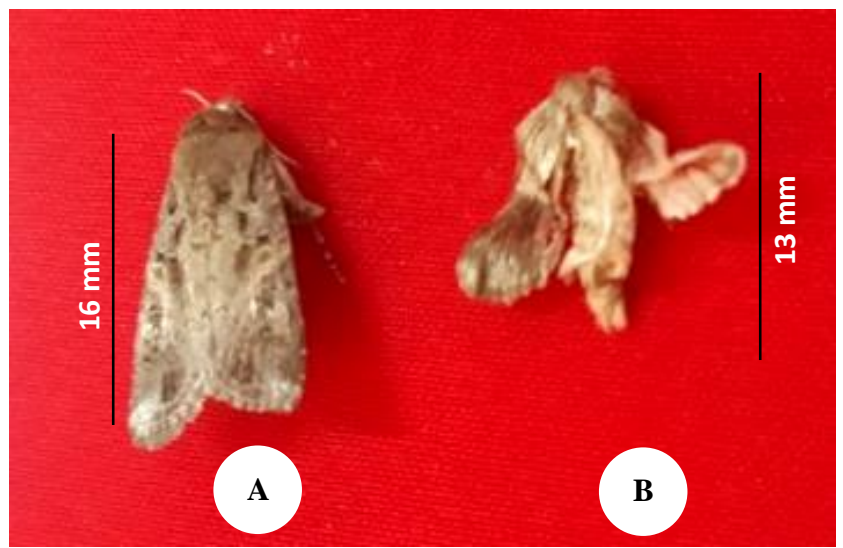

Figure 9. Morphology of Spodoptera frugiperda adults: healthy adults of control (A) and unhealthy with malformation adults infected by endophytic fungi (B)

In this study, the endophytic fungi isolated from maize, banana and chili roots were able to colonize the plant tissue, both the stems and leaves of maize. The congruent results were also found by Renuka et al. (2016) stating that the endophytic $B$. bassiana colonized the maize leaf and stem tissue. The colonized maize tissues had a characteristic of mycelia fungal color that varies depending on the species of fungus and this characteristic is in line with the results of the study by Jones et al. (2018).

The existence of endophytic fungi in the plant tissues is an association that is mutually beneficial; the fungi get a habitat and niche, while the plants get protection from pests (Jones et al. 2018) and promote growth due to the presence of the endophytic fungi (Barra-Bucarei et al. 2020; Jaber and Ownley 2018). The data in this study prove that the plants inoculated with the endophytic fungi tended to be taller with more and longer roots than the untreated plants. In addition, the treated plants looked healthy and showed no symptoms of illness. These are the preliminary data to 
be the basis for future studies on the effect of the endophytic fungus on plant growth.

The endophytic fungal isolates in this study isolated from the root tissues of maize, banana and chili, and the isolates were then re-inoculated through the roots again and proved to enter the maize stalks and leaves systemically as seen from the presence of mycelia in the entire plant stems and leaf tissues. Barra-Bucarei et al. (2020) state that endophytic fungal isolates have the ability to have a systemic mode of action. The results of detection by Carolina et al. (2020) show that the endophytic fungi can still be found in the roots, stems and leaves up to 30 days after inoculation. However, according to Shikano (2018), the endophytic fungi are able to colonize plant parts for several months and the duration of their persistence in the plant tissue varies depending on the age of the plant (high persistence in young tissues). The high fungal persistence in the plant tissues has the potential to develop seed treatment for maize seeds. The seed treatment through seeds allows the endophytic to colonize the plant and prevents $S$. frugiperda larvae from attacking the leaves, stems, and shoots.

In this study, the mortality of larvae treated with the endophytic fungal suspension $\left(1 \times 10^{6}\right.$ conidia $\left.\mathrm{mL}^{-1}\right)$ was $29.33 \%$. This result is similar to the study results of Akutse et al. (2019) on the endophytic B. bassiana which caused the mortality of $S$. frugiperda larvae for only $30 \%$. According to Resquín-Romero et al. (2016), the mortality by the endophytic fungi can increase if the spore concentration is increased to $1 \times 10^{8}$ conidia $\mathrm{mL}^{-1}$ and the mortality can range from $41.70-50.00 \%$ and it is higher when the application of the combination of the insects eats the part of the colonized tissue by the fungus and in contact. Ramos et al. (2020) stated that the mortality caused by the endophytic B. bassiana reached $87 \%$ while that caused by the endophytic $M$. anisopliae reached $75 \%$. The variations in the mortality data indicate that the pathogenicity of the fungus depends on the strain of the fungus. In addition, variations in the application method of the fungus also affect mortality. The combination of the fungal treatment in contact with insects and fungi entering through the eaten inoculated leaves can increase the effectiveness of the fungus. In this study, there were two isolates that caused higher mortality of $S$. frugiperda larvae, namely JgCrJr isolate of Beauveria sp. (29.33\%) and JgSPK isolate of Beauveria sp. (26.67\%). The two isolates were isolated from the maize root tissue and this finding is interesting because of the high potential to successfully kill $S$. frugiperda larvae hidden in leaf midribs due to the systemic nature of fungi able to colonize maize leaves and stalks. The potential for fungus to be developed as a seed treatment for maize seeds is also high because of the high ability of fungi to colonize roots.

The endophytic fungi in this experiment also decreased the appetite of $S$. frugiperda larvae. The decreased appetite resulted in weight loss. The decrease in appetite was significant on the sixth day after the spray of the fungal conidia. According to El-Ghany (2015), this decreased appetite of the larvae was due to continuing fungal infection. The infection occurs when the fungal conidia germinate and can penetrate the host insect's integument (Fernandes et al. 2007). Then, the germ tubes produce specific infection hyphae (El-Ghany 2015). The hyphae spread to the hemolymph and develop to produce blastospores capable of producing proteolytic or chitinolytic enzymes which can disrupt normal cell metabolism (Mancillas-Paredes et al. 2019) whose symptoms can be seen from the decreased appetite of host larvae. Then, the toxins from secondary metabolites begin to kill the host insect (El-Ghany 2015).

The larvae and pupae that got sick or die after being inoculated with the conidia of endophytic fungi were generally stiff, and the body was smaller, shriveled, hardens like a mummy, and over time the body changed color to black but did not smell. The mycelia and the fungal conidia enveloped the cadaver. In addition, the morphology of pupae and adults becomes abnormal and malformed. The symptoms of these sick larvae and pupae are similar to those found by Herlinda et al. (2020b). The folded wings of adults can cause them to be unable to copulate and thus indirectly lead to a decrease in the population density of the next generation.

Finally, this study found that the endophytic fungi were isolated from the root tissue of maize, banana, and chili from the lowlands to highlands of South Sumatra as many as eight isolates consisting of the genus, Aspergillus sp., Beauveria sp., Chaetomium sp., and Curvularia sp. The two most pathogenic isolates against $S$. frugiperda larvae were found from the roots of maize, namely $\mathrm{JgCrJr}$ isolate (Beauveria sp.) and JgSPK isolates (Beauveria sp.) with mortality of $29.33 \%$ and $26.67 \%$, respectively. The isolate $\mathrm{JgCrJr}$ (Beauveria sp.) can reduce the emergence of $S$. frugiperda adults up to $44 \%$. Consequently, The two endophytic fungal isolates of Beauveria sp. have a high potential to be developed to control S. frugiperda larvae in maize in both the lowlands and the highlands.

\section{ACKNOWLEDGEMENTS}

This research was funded by the Program of Professor Research Grant (Penelitian Unggulan Profesi) of Universitas Sriwijaya, Indonesian, with a budget year of 2020, contract number: SP DIPA-023.17.2.677515/2020, 16 March 2020 with contract revision of number: 0687/UN9/SK.BUK.KP/2020, 15 July 2020 chaired by SH. Special thanks to Dr. Radix Suharjo, a microbiologist from Universitas Lampung, Indonesia for identification of the fungi.

\section{REFERENCES}

Ahmad I, Jiménez-gasco M, Luthe DS, Shakeel SN, Barbercheck ME. 2020. Endophytic Metarhizium robertsii promotes maize growth, suppresses insect growth, and alters plant defense gene expression. Biol Control 144: 1-10. DOI: 10.1016/j.biocontrol.2019.104167.

Akutse KS, Kimemia JW, Ekesi S, Khamis FM, Ombura OL, Subramanian S. 2019. Ovicidal effects of entomopathogenic fungal isolates on the invasive fall armyworm Spodoptera frugiperda (Lepidoptera: Noctuidae). J Appl Entomol 143: 626-634. DOI: 10.1111/jen.12634. 
Assaf LH, Haleema RA, Abdullah SK. 2011. Association of entomopathogenic and other opportunistic fungi. Jordan J Biol Sci 4: 87-92.

Ayudya DR, Herlinda S, Suwandi S. 2019. Insecticidal activity of culture filtrates from liquid medium of Beauveria bassiana isolates from South Sumatra (Indonesia) wetland soil against larvae of Spodoptera litura. Biodiversitas 20: 2101-2109. DOI: 10.13057/biodiv/d200802.

Bamisile BS, Akutse KS, Dash CK, Qasim M, Aguila LCR, Ashraf HJ, et al. 2020. Effects of seedling age on colonization patterns of citrus limon plants by endophytic Beauveria bassiana and Metarhizium anisopliae and their influence on seedlings growth. J Fungi 6: 1-15. DOI: $10.3390 /$ jof6010029.

Bamisile BS, Dash CK, Akutse KS, Qasim M, Aguila LCR, Wang F, et al. 2019. Endophytic Beauveria bassiana in foliar-treated citrus limon plants acting as a growth suppressor to three successive generations of Diaphorina citri Kuwayama (Hemiptera: Liviidae). Insects 10: 1-15. DOI: $10.3390 /$ insects10060176.

Barra-Bucarei L, González MG, Iglesias AF, Aguayo GS, Peñalosa MG, Vera PV. 2020. Beauveria bassiana multifunction as an endophyte: growth promotion and biologic control of Trialeurodes vaporariorum, (Westwood) (Hemiptera: Aleyrodidae) in tomato. Insects 11: 1-15. DOI: 10.3390/insects11090591.

Bateman ML, Day RK, Luke B, Edgington S, Kuhlmann U, Cock MJW. 2018. Assessment of potential biopesticide options for managing fal armyworm (Spodoptera frugiperda) in Africa. J Appl Entomol 142: 805-819. DOI: $10.1111 /$ jen.12565.

Bentivenha JPF, Baldin ELL, Montezano DG, Hunt TE, Paula-Moraes S V. 2017. Attack and defense movements involved in the interaction of Spodoptera frugiperda and Helicoverpa zea (Lepidoptera: Noctuidae). J Pest Sci 90: 433-445. DOI: 10.1007/s10340-016-0802-

Boaventura D, Martin M, Pozzebon A, Mota-Sanchez D, Nauen R. 2020. Monitoring of target-site mutations conferring insecticide resistance in Spodoptera frugiperda. Insects 11: 1-11. DOI: 10.3390/insects11080545.

Carolina A, Silva L, Silva GA, Henrique P, Abib N, Carolino AT, et al 2020. Endophytic colonization of tomato plants by the entomopathogenic fungus Beauveria bassiana for controlling the South American tomato pinworm, Tuta absoluta. CABI Agric Biosci 1: 1-9. DOI: 10.1186/s43170-020-00002-x.

El-Ghany TMA. 2015. Entomopathogenic Fungi and their Role in Biological Control. Biology Department Faculty of Science Jazan University KSA: Cairo. DOI: 10.4172/978-1-63278-065-2-66.

Elfita, Mardiyanto, Fitrya, Larasati JE, Julinar, Widjajanti H, et al. 2019 Antibacterial activity of Cordyline fruticosa leaf extracts and it endophytic fungi extracts. Biodiversitas 20: 3804-3812. DOI: 10.13057/biodiv/d201245

Fernandes EKK, Rangel DEN, Moraes AM., Bittencourt VREP, Roberts DW. 2007. Variability in tolerance to UV-B radiation among Beauveria spp. isolates. J Invertebr Pathol 96: 237-243. DOI 0.1016/j.jip.2007.05.007.

Flagel L, Lee YW, Wanjugi H, Swarup S, Brown A, Kraft E, et al. 2018. Mutational disruption of the $\mathrm{ABCC} 2$ gene in fall armyworm, Spodoptera frugiperda, confers resistance to the Cry1Fa and Cry1A. Sci Rep 8: 1-11. DOI: 10.1038/s41598-018-25491-9.

Ginting S, Zarkani A, Wibowo RH, Sipriyadi. 2020. New invasive pest, Spodoptera frugiperda (J. E. Smith) (Lepidoptera: Noctuidae) attacking corn in Bengkulu, Indonesia. Serangga 25: 105-117.

De Groote H, Kimenju SC, Munyua B, Palmas S, Kassie M, Bruce A. 2020. Spread and impact of fall armyworm (Spodoptera frugiperda J.E. Smith) in maize production areas of Kenya. Agric Ecosyst Environ 292: 1-10. DOI: 10.1016/j.agee.2019.106804

Gustianingtyas M, Herlinda S, Suwandi, Suparman, Hamidson H, Hasbi, et al. 2020. Toxicity of entomopathogenic fungal culture filtrate of lowland and highland soil of South Sumatra (Indonesia) against Spodoptera litura larvae. Biodiversitas 21: 1839-1849. DOI: $10.13057 /$ biodiv/d210510.

Gutiérrez-moreno R, Mota-sanchez D, Blanco CA, Whalon ME, Teránsantofimio H, Rodriguez-maciel JC, et al. 2018. Field-evolved resistance of the fall armyworm (Lepidoptera: Noctuidae) to synthetic insecticides in Puerto Rico and Mexico. J Econ Entomol 20: 1-11. DOI: $10.1093 /$ jee/toy 372

Herlinda S, Efendi RA, Suharjo R, Hasbi, Setiawan A, Elfita, et al. 2020a. New emerging entomopathogenic fungi isolated from soil in South Sumatra (Indonesia) and their filtrate and conidial insecticidal activity against Spodoptera litura. Biodiversitas 21: 5102-5113. DOI:
$10.13057 /$ biodiv/d211115

Herlinda S, Octariati N, Suwandi S. 2020b. Exploring entomopathogenic fungi from South Sumatra (Indonesia) soil and their pathogenicity against a new invasive maize pest, Spodoptera frugiperda. Biodiversitas 21: 2955-2965. DOI: 10.13057/biodiv/d210711.

Humber RA. 2005. Entomopathogenic Fungal Identification. USDA-ARS Plant Protection Research Unit: Ithaca.

Hutasoit RT, Kalqutny SH, Widiarta IN. 2020. Spatial distribution pattern, bionomic, and demographic parameters of a new invasive species of armyworm Spodoptera frugiperda (Lepidoptera; Noctuidae) in maize of South Sumatra, Indonesia. Biodiversitas 21: 3576-3582. DOI: $10.13057 / \mathrm{biodiv} / \mathrm{d} 210821$

Jaber LR, Ownley BH. 2018. Can we use entomopathogenic fungi as endophytes for dual biological control of insect pests and plant pathogens? Biol Control 116: 36-45. DOI: 10.1016/j.biocontrol.2017.01.018.

Jones S, Behie SW, Jones SJ, Bidochka MJ, Hyde K. 2018. Plant tissue localization of the endophytic insect pathogenic fungi ScienceDirect Plant tissue localization of the endophytic insect pathogenic fungi Metarhizium and Beauveria. Fungal Ecol 13: 112-119. DOI: 10.1016/j.funeco.2014.08.001.

Kasambala T, Vega FE, Klingen I. 2018. Establishment of the fungal entomopathogen Beauveria bassiana as an endophyte in sugarcane, Saccharum officinarum. Fungal Ecol 35: 70-77. DOI: 10.1016/j.funeco.2018.06.008.

Lestari P, Budiarti A, Fitriana Y, Susilo FX, Swibawa IG. 2020. Identification and genetic diversity of Spodoptera frugiperda in Lampung Province , Indonesia. Biodiversitas 21: 1670-1677. DOI: $10.13057 /$ biodiv/d210448

Lira AC de, Mascarin GM, Júnior ID. 2020. Microsclerotia production of Metarhizium spp. for dual role as plant biostimulant and control of Spodoptera frugiperda through corn seed coating. Fungal Biol 124: 689-699. DOI: 10.1016/j.funbio.2020.03.011.

Machado BB, Orue JPM, Arruda MS, Santos C V., Sarath DS, Goncalves WN, et al. 2016. BioLeaf: A professional mobile application to measure foliar damage caused by insect herbivory. Comput Electron Agric 129: 44-55. DOI: 10.1016/j.compag.2016.09.007.

Mancillas-Paredes J, Hernández-Sánchez H, Jaramillo-Flores ME, GarcíaGutiérrez C. 2019. Proteases and chitinases induced in Beauveria bassiana during infection by Zabrotes subfasciatus. Southwest Entomol 44: 125-137. DOI: 10.3958/059.044.0114.

Montezano DG, Specht A, Sosa-gómez DR, Brasília U De. 2018. Host plants of Spodoptera frugiperda (Lepidoptera: Noctuidae) in the Americas. Afr Entomol 26: 286-300. DOI: 10.4001/003.026.0286.

Nagoshi RN, Fleischer S, Meagher RL, Hay-roe M, Silvie P, Vergara C, et al. 2017. Fall armyworm migration across the Lesser Antilles and the potential for genetic exchanges between North and South American populations. PLoS One 12: e0171743. DOI: 10.1371/journal. pone.0171743.

Otim MH, Tay WT, Walsh TK, Kanyesigye D, Adumo S, Abongosi J, et al. 2018. Detection of sister-species in invasive populations of the fall armyworm Spodoptera frugiperda (Lepidoptera: Noctuidae) from Uganda. PLoS One 13: e0194571. DOI: 10.1371/journal.pone.0194571.

Qi G, Lan N, Ma X, Yu Z, Zhao X. 2011. Controlling Myzus persicae with recombinant endophytic fungi Chaetomium globosum expressing Pinellia ternata agglutinin using recombinant endophytic fungi to control aphids. J Appl Microbiol 110: 1314-1322. DOI: 10.1111/j.1365-2672.2011.04985.x

Ramanujam B, Poornesha B, Shylesha AN. 2020. Effect of entomopathogenic fungi against invasive pest Spodoptera frugiperda (J.E. Smith) (Lepidoptera : Noctuidae) in maize. Egypt J Biol Pest Control 30: 1-5. DOI: 10.1186/s41938-020-00291-4.

Ramirez-Rodriguez D, Sánchez-Peña SR. 2016. Endophytic Beauveria bassiana in Zea mays: pathogenicity against larvae of fall armyworm, Spodoptera frugiperda. Southwest Entomol Sci Note 41: 875-878.

Ramos Y, Taibo AD, Jiménez JA, Portal O. 2020. Endophytic establishment of Beauveria bassiana and Metarhizium anisopliae in maize plants and its effect against Spodoptera frugiperda (J. E. Smith) (Lepidoptera: Noctuidae) larvae. Egypt J Biol Pest Control 30: 1-6. DOI: 10.1186/s41938-020-00223-2.

Renuka S, Ramanujam B, Poornesha B. 2016. Endophytic ability of different isolates of entomopathogenic fungi Beauveria bassiana (Balsamo) Vuillemin in stem and leaf tissues of maize (Zea mays L.). Indian J Microbiol 56: 126-133. DOI: 10.1007/s12088-016-0574-8.

Resquín-Romero G, Garrido-Jurado I, Delso C, Ríos-Moreno A, Quesada- 
Moraga E. 2016. Transient endophytic colonization of plants improve the outcome of foliar applications of mycoinsecticides against chewing insects. J Invertebr Pathol 136: 23-31. DOI: 10.1016/j.jip.2016.03.003.

Russo ML, Jaber LR, Scorsetti AC, Vianna F, Cabello MN, Pelizza SA 2020. Effect of entomopathogenic fungi introduced as corn endophytes on the development, reproduction, and food preference of the invasive fall armyworm Spodoptera frugiperda. J Pest Sci 93: 112. DOI: 10.1007/s10340-020-01302-X.

Sartiami D, Dadang, Harahap I, Kusumah Y, Anwar R. 2020. First record of fall armyworm (Spodoptera frugiperda) in Indonesia and its occurrence in three provinces. IOP Conf Ser Earth Environ Sci 468: 012021. DOI: $10.1088 / 1755-1315 / 468 / 1 / 012021$.

Shikano I. 2018. Evolutionary ecology of multitrophic interactions between plants, insect herbivores and entomopathogens. J Chem Ecol 43: 586-598. DOI: 10.1007/s10886-017-0850-z

Silva LF, Freire KTLS, Araújo-Magalhães GR, Agamez-Montalvo GS, Sousa MA, Costa-Silva TA, et al. 2018. Penicillium and Talaromyces endophytes from Tillandsia catimbauensis, a bromeliad endemic in the Brazilian tropical dry forest, and their potential for 1-asparaginase production. World J Microbiol Biotechnol 34: 1-12. DOI: 10.1007/s11274-018-2547-z.

Sumikarsih E, Herlinda S, Pujiastuti Y. 2019. Conidial density and viability of Beauveria bassiana isolate from Java and Sumatra and their virulence against Nilaparvata lugens at different temperatures. Agrivita 41: 335-349. DOI: 10.17503/agrivita.v41i2.2105.

Tambo JA, Day RK, Lamontagne-Godwin J, Silvestri S, Beseh PK, Oppong-mensah B, et al. 2020. Tackling fall armyworm (Spodoptera frugiperda) outbreak in Africa: an analysis of farmers' control actions. Intl J Pest Manag 66: 298-310. DOI: 10.1080/09670874.2019.1646942.

Wicklow DT, Dowd P. F, Gloer JB. 2000. Chaetomium mycotoxins with antiinsectan or antifungal activity. In: Proceedings of International Symposium of Mycotoxicology '99, September 9-10, 1999, Chiba, Japan. Mycotoxins: Supplement 99. In: Kumagi S (ed.). Mycotoxin Contamination: Health Risk and Prevention Project. Matsumoto Printing Co., Tokyo. 